\title{
Influences of Sex and Age on the Hematological Profile of the Jundiá (Silver Catfish) Rhamdia quelen
}

\author{
Nivaldo Ferreira do Nascimento* and Laura Satiko Okada Nakaghi \\ Centro de Aquicultura da Universidade Estadual Paulista (CAUNESP), Jaboticabal 14884-900, Brazil \\ Cleonice Cristina Hilbig and Arlene Sobrinho Ventura \\ Universidade Federal da Grande Dourados, Dourados, Mato Grosso do Sul, Brazil
}

Ana Carolina Barni de Azevedo

Universidade Federal do Paraná, Curitiba, Paraná, Brazil

Andressa Fierli Dean and Robie Allan Bombardelli

Universidade Estadual do Oeste do Paraná, Toledo, Paraná, Brazil

\begin{abstract}
In this study, sex and age influenced the hematological profiles of Jundiá (Silver Catfish) Rhamdia quelen. Females showed lower levels of hemoglobin, young fish increased lymphocyte counts, and older fish increased hematocrit values. These results indicate that, depending on age and sex, the fish have disparate hematological profiles. For this reason, it is important to consider the sex and age of an $R$. quelen when examining the impact of environmental and management factors on this species in terms of their hematological profiles.
\end{abstract}

Hematology can be used to study the responses of fish to different environmental and management conditions, allowing for a greater understanding of their physiology and the development of optimal environments. Several factors capable of altering the blood parameters of fish have been described, notably diet (Camargo et al. 2005), stage of sexual maturity (Santos et al. 2009), stress (Neves et al. 2014), water pollution (Brum et al. 2014), parasitism (Figueiredo et al. 2014), sex (Onyia et al. 2013), seasonality, and age (Fallah et al. 2014). Furthermore, hematological analysis can be used in the diagnosis and treatment of diseases (Ranzani-Paiva et al. 2013).

The Jundiá (Silver Catfish) Rhamdia quelen is an important aquaculture species in temperate and subtropical climates of South America. Borges et al. (2004) analyzed the hematology of $R$. quelen males, and their findings provide benchmark values for blood profiles. However, these authors did not analyze the influences that age and sex may have on hematology. Both age and sex have been demonstrated to affect hematological parameters (Hrubec et al. 2001; Acharya and Mohanty 2014; Fallah et al. 2014). Thus, the aim of this study was to analyze the hematological parameters in male and female $R$. quelen of different ages to determine whether there are disparate hematological baselines among members of this species.

\section{METHODS}

The study took place at the Instituto de Pesquisa em Aquicultura Ambiental (Research Institute for Environment Aquaculture) of the Universidade Estadual do Oeste do Paraná, Toledo, Paraná, Brazil, and was approved by the Ethics Committee for the Use of Animals of the Universidade Estadual Paulista (protocol 014235/13)

In July 2013, 40 male and 40 female $R$. quelen of three different ages (1, 2, and 4 years old) were selected from different ponds at the institute and placed in a single $200-\mathrm{m}^{2}$ pond $(n=240)$, resulting in an initial density of $1.2 \mathrm{fish} / \mathrm{m}^{2}$. For further identification, each fish had a microchip (AnimallTAG) inserted in its dorsal muscle while anesthetized with benzocaine $(0.75 \mathrm{mg} / \mathrm{L})$.

*Corresponding author: nivaldotec@yahoo.com.br

Received May 24, 2015; accepted March 24, 2016 
The fish were fed an experimental diet with $38 \%$ crude protein and $9.5 \%$ lipids twice daily to apparent satiety. In October 2013 and January 2014, 90 fish were removed for spawning induction, leaving 150 in the pond at a density of $0.75 \mathrm{fish} / \mathrm{m}^{2}$. In April 2014 (after the spawning period), 38 fish divided into the following groups were randomly selected for hematological analysis: age- 1 females $(n=5 ; 286.0 \pm 59.4 \mathrm{~g}$ [mean $\pm \mathrm{SE}])$ and males $(n=5 ; 254.0 \pm 97.6 \mathrm{~g})$; age-2 females $(n=7 ; 490.0 \pm 117.3 \mathrm{~g})$ and males $(n=7 ; 401.4 \pm 98.6 \mathrm{~g})$; and age-4 females $(n=7 ; 624.3 \pm 65.5 \mathrm{~g})$ and males $(n=7 ; 452.9$ $\pm 76.7 \mathrm{~g}$ ).

In the morning and afternoon, water temperature $\left({ }^{\circ} \mathrm{C}\right.$ [daily]; YSI 500A), dissolved oxygen (mg/L [daily]; YSI 500A), and $\mathrm{pH}$ (weekly; Tectal Tec 5) were measured, resulting in the following mean \pm SE values: $20.16 \pm 3.75^{\circ} \mathrm{C}$ and $22.47 \pm 3.57^{\circ} \mathrm{C}, 4.81 \pm 1.13$ and $5.67 \pm 1.27 \mathrm{mg} / \mathrm{L}$, and $7.01 \pm 0.39$ and $7.40 \pm 0.63$. The mean total ammonia concentration (measured monthly) was $0.037 \pm$ $0.012 \mathrm{mg} / \mathrm{L}$, as determined by the method of Koroleff (1976).

A $2 \times 3$ factorial experimental design was used, in which two sex and three age-groups were analyzed. Fish were not fed for $24 \mathrm{~h}$ prior to blood sampling. On the day of sampling, they were captured in a trawl and anesthetized with benzocaine $(0.75 \mathrm{mg} / \mathrm{L})$; blood $(2 \mathrm{~mL})$ was then collected from the caudal vessel using a syringe without anticoagulant and transferred to two test tubes, one of which contained $10 \%$ EDTA.

Total plasma protein analysis.-The blood samples were centrifuged for $20 \mathrm{~min}$ at 2,060 $\times \mathrm{g}$ (Baby I $206 \mathrm{BL}$; FANEM), and the serum aspirated and stored at $-20^{\circ} \mathrm{C}$. Total plasma protein analysis was performed by spectrophotometry using the commercial kit Gold Analisa.

Erythrogram.-The blood samples containing EDTA were used to obtain erythrocyte counts (in a Neubauer chamber), hematocrit values (using the micro-hematocrit method of Goldenfarb et al. 1971), and hemoglobin values (using the cyanomethemoglobin method of Collier 1944). These results were used to calculate three red blood cell indices: mean corpuscular volume (MCV), mean corpuscular hemoglobin $(\mathrm{MCH})$, and mean corpuscular hemoglobin concentration (MCHC), following Wintrobe (1934).

Leukogram, thrombogram, and leukocyte differential.Blood smears were stained with an InstantProv fast-staining kit to obtain total leukocyte and thrombocyte counts and for leukocyte differential analysis (Ranzani-Paiva et al. 2013)

The data were analyzed by ANOVA using Tukey's test in the program Statistica 10 (StatSoft, USA), with the significance level being set at 0.05 .

\section{RESULTS}

Sex had a significant effect $(P<0.01)$ on hemoglobin levels and consequently on MCHC, with males showing greater values for these parameters independent of age. Age had a significant effect $(P<0.05)$ on hematocrit percentage, with 4-year-old fish having higher values than 1-year-old fish (Table 1). Neither age nor sex had a significant effect on total plasma protein levels.

One-year-old fish had significantly higher $(P<0.05)$ total thrombocyte and lymphocyte counts than age- 2 and age- 3 fish, with females having the highest values (Table 2). One-yearold females also had higher total leukocyte counts than older males (Table 2).

\section{DISCUSSION}

We determined the influences of sex and age on the hematological profiles of $R$. quelen. The high values of hemoglobin and MCHC for males may be due to genetically determined differences in the metabolic rates between the sexes and the greater aggression among males, as has been observed for Walking Catfish Clarias batrachus (Acharya and Mohanty 2014).

The greater hematocrit and hemoglobin levels observed in older fish indicate higher red blood cell production, enabling greater transport of oxygen. Similar results have been reported by Hrubec et al. (2001) in older hybrid tilapia Oreochromis spp. and by Orun and Erdeml (2002) in Longspine Scraper Capoeta trutta, in which older fish showed the highest hematocrit values.

The values of total plasma protein that we obtained were above the standards established by Borges et al. (2004) and were not different among treatments. Additionally, the number of erythrocytes, MCV, and $\mathrm{MCH}$ were not affected by sex or age. In contrast, Tavares-Dias et al. (2002) reported greater erythrocyte counts among young $R$. quelen than studies examining older individuals of the same species (Foresti et al. 1977; Kavamoto et al. 1983). Nevertheless, the erythrocyte count observed in this study corroborates the degree of variation determined by these authors.

Orun and Erdeml (2002) stated that lymphocytes are essential in young fish, and Bahmani et al. (2001) observed that young Beluga Huso huso had higher numbers of leukocytes. Therefore, the higher leukocyte and lymphocyte levels that we observed in age-1 fish could indicate a requirement of the immune system, and as females displayed higher values than males this response could be influenced by sex or age. However, further studies with larger sample sizes that explore more variables will be necessary to obtain better comprehension of these phenomena.

Thrombocyte levels can increase under stress (e.g., capture; Tavares-Dias and Oliveira 2009). According to Koakoski et al. (2012), R. quelen of different ages respond differently to the same stress factor, with cortisol peaks varying with age. Thus, the greater number of thrombocytes observed in age-1 fish could be due to age-related differences in fish's responses to the handling practices employed. 


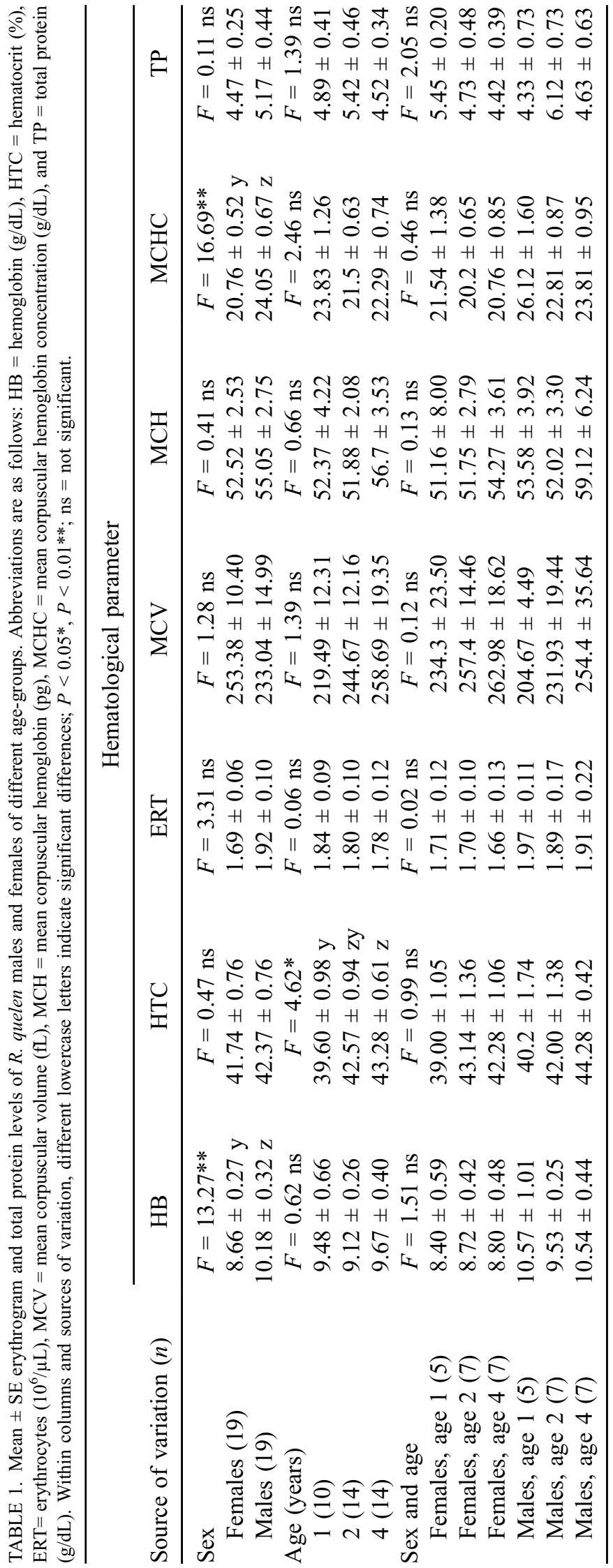




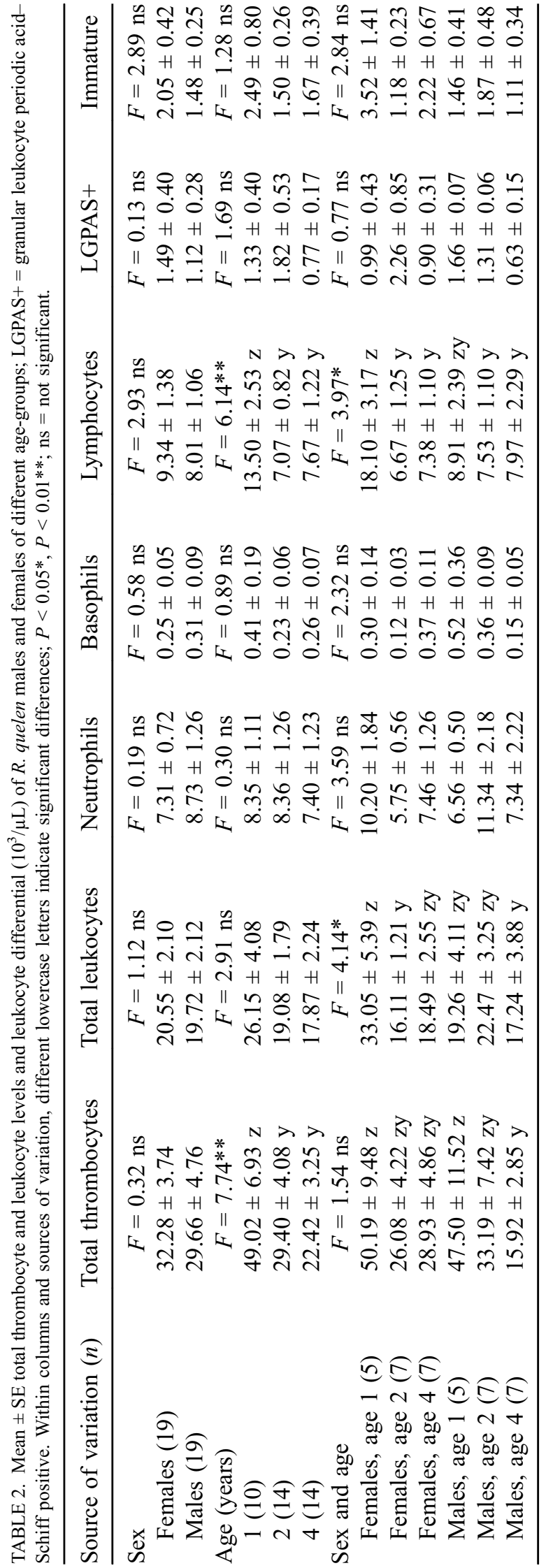


In summary, in our study females showed lower levels of hemoglobin, young fish greater lymphocyte counts, and older fish greater hematocrit values. Our data thus indicate that age and sex must be considered in laboratory studies of hematological parameters, as the results could be affected by these variables. In particular, studies addressing the influence of survival, reproduction, and resistance to parasitism on hematological variables must take age and sex into account.

\section{ACKNOWLEDGMENTS}

The authors would like to thank the Instituto de Pesquisas em Aquicultura Ambiental for providing the infrastructure for this project and the Conselho Nacional de Desenvolvimento Científico e Tecnológico for financial support.

\section{REFERENCES}

Acharya, G., and P. K. Mohanty. 2014. Haematological and serum biochemical parameters in different sexes of Walking Catfish, Clarias batrachus (Linnaeus, 1758). International Journal of Science and Research 3:1914-1917.

Bahmani, M., R. Kazemi, and P. Donskaya. 2001. A comparative study of some hematological features in young reared sturgeons (Acipenser persicus and Huso huso). Fish Physiology and Biochemistry 24:135-140.

Borges, A., L. Scotti, D. Siqueira, D. Jurinitz and G. Wassermann. 2004. Hematologic and serum biochemical values for jundiá (Rhamdia quelen). Fish Physiology and Biochemistry 30:21-25.

Brum, A., G. Dotta, K. Roumbedakis, E. L. Goncalves, L. P. Garcia, P. Garcia, V. M. Scussel, and M. L. Martins. 2014. Hematological and histopathological changes in Silver Catfish Rhamdia quelen (Siluriformes) exposed to clomazone herbicide in the Madre River, Santa Catarina State, southern Brazil. Journal of Environmental Science and Health 49:169-175.

Camargo, S. O., J. L. Pouey, and C. Martins. 2005. Parâmetros eritrocitários do jundiá (Rhamdia quelen) submetido à dieta com diferentes níveis de proteína. [Erythrocytic parameters of jundiá (Rhamdia quelen) subjected to diets with different levels of protein.] Ciência Rural 35:1406-1411.

Collier, H. B. 1944. The standardizations of blood hemoglobin determinations. Canadian Medical Association Journal 50:550-552.

Fallah, F., H. Khara, J. Roohi, and M. Boorani. 2014. Hematological parameters of pike Esox lucius in relation to different ages and seasons. Comparative Clinical Pathology 23:949-953.

Figueiredo, A. B., K. R. Tancredo, G. S. Hashimoto, K. Roumbedakis, C. Marchiori Nda, and M. L. Martins. 2014. Haematological and parasitological assessment of Silver Catfish Rhamdia quelen farmed in southern Brazil. Revista Brazileira de Parasitologia Veterinária 23:157-163.
Foresti, F., G. Volpato, E. Garcia, and E. Caramaschi. 1977. Medidas de alguns parâmetros morfológicos e fisiológicos do sangue de bagre (Rhamdia hilarii Valenciennes, 1840) (Pisces: Pimelodidae). [Measurement of some morphological and physiological parameters of the blood of the catfish (Rhamdia hilarii Valenciennes, 1840) (Pisces: Pimelodidae).] Ciência e Cultura, Rio de Janeiro 29:580.

Goldenfarb, P. B., F. P. Bowyer, E. Hall, and E. Brosious. 1971. Reproducibility in the hematology laboratory: the microhematocrit determinations. American Journal of Clinical Pathology 56:35-39.

Hrubec, T. C., S. A. Smith, and J. L. Robertson. 2001. Age-related changes in hematology and plasma chemistry values of hybrid Striped Bass (Morone chrysops $\times$ Morone saxatilis). Veterinary Clinical Pathology 30:8-15.

Kavamoto, E. T., M. J. T. Ranzani-Paiva, and M. Tokumaru. 1983. Estudos hematológicos em "bagre," Rhamdia hilarii (Val. 1840), Teleósteo, no estádio de desenvolvimento gonadal maduro. [Hematological studies of the "catfish," Rhamdia hilarii (Val. 1840), a teleost, in the mature stage of gonad development.] Boletim do Instituto de Pesca 10:53-60.

Koakoski, G., T. A. Oliveira, J. G. da Rosa, M. Fagundes, L. C. Kreutz, and L. J. Barcellos. 2012. Divergent time course of cortisol response to stress in fish of different ages. Physiology and Behavior 106: 129-132.

Koroleff, F. 1976. Determination of ammonia. Pages 126-133 in E. Grashoff and E. Kremling, editors. Methods of seawater analysis. Verlag Chemie, Weinheim, Germany.

Neves, M. S., A. L. Barbas, and R. Y. Fujimoto. 2014. Hematology and recovery response in Jacundá, Crenicichla saxatilis (Linnaeus, 1758) after short-term handling stress. Journal of Applied Ichthyology 30:42-47.

Onyia, L., K. Michael, and B. Ekoto. 2013. Haematological profile, blood group, and genotype of Heterobranchus bidorsalis. Net Journal of Agricultural Science 1:69-72.

Orun, I., and A. U. Erdeml. 2002. A study on blood parameters of Capoeta trutta (Heckel, 1843). Journal of Biological Science 8:508-511.

Ranzani-Paiva, M. J. T., S. B. Páuda, M. Tavares-Dias, and M. I. Egami. 2013. Métodos para análise hematológica em peixes. [Methods for hematological analysis in fish.] Eduem, Maringá, Brazil.

Santos, A. G., M. I. Egami, M. J. T. Ranzani-Paiva, and Y. Juliano. 2009. Hematological parameters and phagocytic activity in Fat Snook (Centropomus parallelus): seasonal variation, sex, and gonadal maturation. Aquaculture 296:359-366.

Tavares-Dias, M., J. F. B. Melo, G. Moraes, and F. R. Moraes. 2002. Haematological characteristics of Brazilian teleosts,VI. Parameters of jundiá Rhamdia quelen (Pimelodidae). Ciência Rural 32:693-698.

Tavares-Dias, M., and S. R. Oliveira. 2009. A review of the blood coagulation system of fish. Brazilian Journal of Biosciences 7:205-224.

Wintrobe, M. M. 1934. Variations in the size and hemoglobin content of erythrocytes in the blood of various vertebrates. Folia Haematologica $51: 32-49$. 